\section{Kostbare, gjentatte hamskifter på Radiumhospitalet}

I Tidsskriftet nr. 19/2010 viser Petter Gjersvik ved sin gjennomgang av det nye storsykehusets navn i Oslo hvordan ledelsen i Helse Sør-Øst ikke eier følelse for tradisjon (1). Godt innarbei-

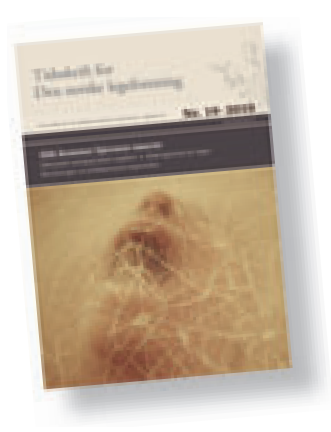

dede navn som Rikshospitalet, Radiumhospitalet, Ullevål sykehus og Aker sykehus forkastes, og navn, tradisjon, følelse og tilhørlighet ofres av helsebyråkratene. Det Gjersvik ikke skriver, er at Radiumhospitalet $\mathrm{i}$ de siste årene har byttet navn, logo på stempler, brevhoder og klær fem ganger etter at Helse Sør-Øst startet med sine herjinger med sykehusene.

Logoene så merkelige ut. De lignet på en sigd, en fortegnet halvmåne og et svart kors. Gjentatte ganger har de prøvd å forbedre dem uten å lykkes, og de er upopulære blant de ansatte.

Ikke bare er det upopulært, hver forandring har også kostet masse penger. Det koster å trykke nye ID-kort med foto, nye konvolutter, brevark, stempler osv.

Derfor er mitt spørsmål: Hva er kostnadnytte-verdien av dette? Hvor mange prostataoperasjoner kunne man ha utført for de mange millionene av kroner som ble brukt på disse meningsløse prosjektene?

\section{Imre Hercz}

hercz@online.no

Høvik legesenter

\section{Litteratur \\ 1. Gjersvik P. Ett sykehus - flere merkevarenavn. Tidsskr Nor Legeforen 2010; 130: 1905.}

\section{Traumebehandling i Norge}

I Tidsskriftet nr. 15/2010 presenterte Dehli og medarbeidere en unders $ø$ kelse av pasienter med alvorlige skader overført til UNN (1). Dette krever noen kommentarer. Alvorlig skadde pasienter utgjør en uensartet gruppe, og å identifisere dem er derfor ikke enkelt. ISS-graderingen som forfatterne bruker, må gjøres retrospektivt. I den akutte fasen består gruppen av alle med mistanke om alvorlige skader, både de som viser seg å ha alvorlige skader, og de som er lettere skadet. Mottakssykehus kan være både lokalsykehus og traumesenter, slik det påpekes i den redaksjonelle kommentaren (2). Det hadde vært bedre om forfatterne også inkluderte pasienter som ble overført på mistanke om alvorlig skade, samt pasienter transportert direkte til traumesenteret.

Vi får ikke presentert resultatene av røntgenundersøkelsene, heller ikke om det var uenighet rundt tolkningen. Lokalsykehusene kritiseres for varierende praksis (bl.a. bruk av CT). Hva har UNN gjort for å oppnå en mer ensartet bildediagnostikk hos traumepasienter i regionen?

Det ble utført få akutte operasjoner, både ved lokalsykehusene og traumesenteret. Alvorlige skader er en dynamisk tilstand, og selv om pasienter senere samme døgn trenger inngrep, betyr ikke det nødvendigvis at disse inngrepene skulle ha vært utført ved lokalsykehusene, fordi behovet kan ha oppstått senere. Funnet viser dog at det er behov for trening i disse sjeldne skadebegrensende prosedyrene, og da kanskje like mye ved lokalsykehusene som ved universitetsklinikken. Artikkelen redegjør heller ikke for tidsforløpet av nødkirurgi for pasienter innlagt direkte ved UNN.

Lokalsykehusene i Nord-Norge var tidlig ute med kompenserende tiltak for lavt traumepasientvolum, og teamtrening startet her (3). Det er således gledelig at UNN nå holder kurs i skadebegrensende kirurgi på linje med resten av landet (4).

Traumesentrenes rolle som pådrivere for god regional traumeomsorg er viktig, men vi bør være varsomme med å kritisere andre sykehus dersom forventningene til hva som skal gjøres lokalt, ikke er avklart. Det betyr selvsagt ikke at man ikke skal se etter forbedringsområder. Det årlige nettverksmøtet i BEST har i mer enn ti år fungert som en slik arena, der små og store fagmiljøer åpent legger frem pasientforløp for diskusjon og konstruktiv kritikk. Norges særegne geografiske og befolkningsmessige utfordringer krever at vi finner løsninger som støtter «kjeden som redder liv», og her er lokalsykehusene viktige også i fremtiden.

\section{Guttorm Brattebø}

Haukeland universitetssykehus og Stiftelsen BEST: Bedre \& systematisk teamtrening

\section{Torben Wisborg}

Hammerfest sykehus

og

Stiftelsen BEST: Bedre \& systematisk teamtrening

Litteratur

1. Dehli T, Bågenholm A, Johnsen L-H et al. Alvorlig skadede overført til universitetssykehus. Tidsskr Nor Legeforen 2010; 130: 1455-7.

2. Hanoa R. Multitraumer og traumesentre. Tidsskr Nor Legeforen 2010; 130: 1446.

3. Wisborg T, Brattebø G, Brinchmann-Hansen $\AA$ et al. Effects of Nationwide Training of Multi-Professional Trauma Teams in Norwegian Hospitals. J Trauma 2008; 64: 1613-8.

4. Hansen KS, Uggen PE, Brattebø $G$ et al. Team-Oriented Training for Damage Control Surgery in Rural Trauma: A New Paradigm. J Trauma 2008: 64: $949-54$

\section{T. Dehli og medarbeidere svarer:}

Vi takker for interessen Brattebø og Wisborg viser for vår artikkel i tidsskriftet (1).

I sin kommentar er de kritiske til studiens inklusjonskriterier, som de mener burde favnet bredere. Vi vil derfor utdype grunnlaget for vårt pasientutvalg (1). Et bærende element i det planlagte nasjonale traumesystemet er optimal samhandling og klar rollefordeling mellom lokalsykehus og traumesenter. Vårt pasientutvalg - et komplett toårsmateriale for alle pasienter med Injury Severity Score $>15$ som ble overført fra lokalsykehus til traumesenter i akuttfasen - er velegnet til å adressere to sentrale elementer i traumesystemet: 1) omfanget av nødkirurgiske prosedyrer og 2) kvaliteten på den bildediagnostikken som lokalsykehuset må basere sine beslutninger på, med hensyn til umiddelbar stabiliserende kirurgi og overføring til traumesenter.

Et hovedfunn er den lave forekomsten av nødkirurgi slik dette er definert i Traumesystem i Norge (2). 14 av 74 pasienter gjennomgikk slike prosedyrer i akuttfasen, hvorav åtte på lokalsykehus. For den aktuelle pasientgruppen gikk det gjennomsnittlig tre måneder mellom hver gang traumesenteret mottok en pasient som hadde gjennomgått et nødkirurgisk inngrep ved et lokalsykehus. Disse dataene bør være en del av beslutningsgrunnlaget for hvordan traumesystemet skal organiseres.

Med hensyn til vår omtale av bildediagnostikken hevder Brattebø og Wisborg at «Lokalsykehusene kritiseres for varierende 
praksis (bl.a. bruk av CT)». Karakteristikken er ikke treffende. Variasjon er ikke nødvendigvis et problem, men avvik fra omforente faglige retningslinjer er det. Samtidig som vi dokumenterer at de aller fleste CT-undersøkelsene er utført lege artis, har vi avdekket et forbedringspotensial: $15 \%$ av CT thorax/buk/bekken er tatt uten intravenøs kontrast, og $16 \%$ av pasientene som ble undersøkt med CT caput, gjennomgikk ingen bildediagnostikk av cervikalcolumna. Radiologisk avdeling, UNN ønsker å ta utgangspunkt i disse funnene i det kommende arbeidet med implementering av den nye traumeorganisasjonen i Helse Nord.

Effektiv diagnostikk og stabiliserende behandling ved lokalsykehus før overføring til traumesenter er bærebjelker i det planlagte nasjonale traumesystemet (2). Vår studie skal ikke leses som kritikk. Vi analyserer sentrale planforutsetninger og påpeker forbedringstiltak som sikter mot at lokalsykehuset best mulig skal fylle sin rolle i overlevelseskjeden.

\section{Trond Dehli}

Hjerte-, lunge- og karkirurgisk avdeling

\section{Anna Bågenholm \\ Liv-Hege Johnsen \\ Radiologisk avdeling}

\section{Svein Are Osbakk}

Knut Fredriksen

Akuttmedisinsk klinikk

\section{Kristian Bartnes}

Hjerte-, lunge- og karkirurgisk avdeling

Universitetssykehuset Nord-Norge

\section{Litteratur}

1. Dehli T, Bågenholm A, Johnsen L-H et al. Alvorlig skadede overført til universitetssykehus. Tidsskr Nor Legeforen 2010; 130: 1455-7.

2. Røise O, Gaarder C, Hansen KS et al. Traumesystem i Norge: forslag til organisering av behandlingen av alvorlig skadde pasienter. Hamar: Helse Øst, 2006

\section{Tvilsom praksis}

I mitt innlegg i Tidsskriftet nr. 18/2010 skrev jeg at vi i Citizens Commissian on Human Rights (CCHR) kontinuerlig er i kontakt med politi, fagmiljøer og medier for å belyse at pasient-

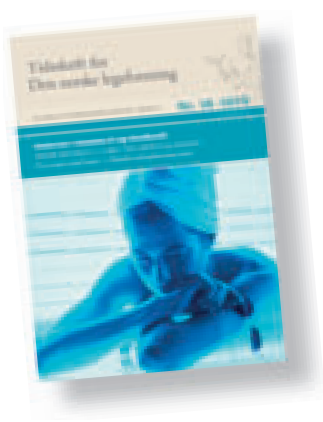
foreningen ADHD Norge mottar mye av sin økonomiske støtte fra produsentene av AD/HD-preparater som Ritalin, Concerta og Stratera (1). Tor Eikeland i ADHD Norge påpekte i Tidsskriftet nr. 22/2010 at de faktiske pengesummene de mottok, ikke var store, og at ADHD Norge ikke har noen etiske problemer med å motta pengegaver fra den farmasøytiske industrien (320 000 kroner i 2008) (2).

Omtrent 16000 barn og unge bruker disse preparatene i Norge i dag. Ritalin og Concerta er amfetaminliknende, narkotiske stoffer som har farlige bivirkninger. Etter vår mening $\mathrm{er} \mathrm{AD} / \mathrm{HD}$-diagnosen en høyst subjektiv og lite målbar betegnelse på en rekke forskjellige symptomer - det er ikke en reell sykdom i ordets rette betydning. Følgelig virker disse stoffene kun til å endre atferd - slik alle narkotiske stoffer gjør.

ADHD Norge forfekter diagnosens gyldighet, og preparatenes fortreffelighet, og mottar økonomisk støtte av ulik størrelse fra produsentene av disse narkotiske stoffene. Videre har ADHD Norge et fagråd som består av bl.a. barne- og ungdomspsykiatere som også aktivt promoterer preparatenes fortreffelighet - og som samarbeider med den farmasøytiske industrien i sine yrker.

CCHR ble stiftet av en gruppe scientologer i samarbeid med psykiateren Thomas Szasz i 1969. Den er en ikke-religiøs og ikke-politisk internasjonal organisasjon som arbeider for å få FNs menneskerettigheter og lov og etikk til å virke i fagfeltet mental helse. Psykiatere, psykologer, leger, avhoppere fra den farmasøytiske industrien samt ofre for feildiagnostisering, feilmedisinering og overgrep fra psykiatrien er aktive i organisasjonen over hele verden. Vi anser bruk av narkotiske stoffer og annen psykofarmaka på barn som alvorlige brudd på deres rettigheter, og vi vil spre kunnskap om dette til alle involverte parter - helt til en større opprydding av situasjonen finner sted.

Pasientstøttegruppers kobling med den farmasøytiske industrien, og psykiatere som jobber i begge disse leirene, er en høyst aktuell problemstilling for oss i vårt virke. ADHD Norge er langt fra noe unntak snarere tvert imot siden det er barn og ungdom det handler om her.

\section{Hans-Erik Dyvik Husby \\ CCHR Norge}

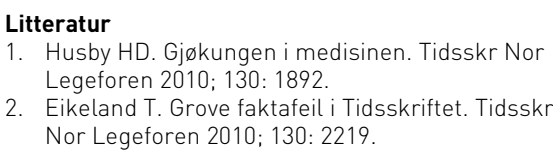

\section{Kun datamodellar, ikkje fakta}

Eg noterer meg at Helge Drange \& Gunnar Kvåle i Tidsskriftet nr. 17/2010 brukar omgrepet klimaendring (1). Kvifor brukar dei ikkje global oppvarming - for det er vel det som har vore problemet? Eller skal $\mathrm{CO}_{2}$ no få skulda for ei ikkje usannsynleg nedkjøling dei komande åra også?

Det er ikkje rett at vitskapen har doku- mentert at $\mathrm{CO}_{2}$ har avgjerande betydning for klimaet. Eg kjenner ikkje til forsking som viser at ein auke av innhaldet av drivhusgassar påverkar klimaet vesentleg. Men satelittmålingar indikerer at ein dobling av $\mathrm{CO}_{2}$-innhaldet $\mathrm{i}$ atmosfæren vil kunne gje ein temperaturauke på ca. 0,5 grader celsius. Videre at mennesket sitt bidrag til denne auken er ca. $4 \%$, det vil seie at vi vil vere «ansvarlege» for ein temperaturauke på 0,02 grader. Drange og co. kan spare seg å vise til National Academy of Science: Konsensus bygd på modellar liksom Intergovernmental panel on climate change (IPCC) gjer, provar etter mi meining knapt nokon ting så lenge desse modellane ikkje gjer greie for den viktigaste drivhusgassen: vassdamp.

Professor Richard Lindzen ved Massachusetts Institute of Technology (MIT) og andre forskarar har i løpet av 20 år gjort målingar når det gjeld varmeutstrålinga frå jorda, noko som er avgjerande for temperaturutviklinga $(2,3)$. Christopher Monckton gjer i eit foredrag greie for dette sentrale punktet i klimaspørsmålet og mange andre påstandar frå IPCC (4).

\section{Gunnar Saunes}

Ulsteinvik

\section{Litteratur}

1. Drange $H$, Kvåle G. Ikkje tru, men fakta. Tidsskr Nor Legeforen 2010: 130: 1704

2. Spencer R, Braswell WD. Potential Biases in Feedback Diagnosis from Observational Data: A Simple Model Demonstration. Journal of Climate 2007; 21 5624-28.

3. Douglas DH, Christy JR, Person BDP et al. A comparison of tropical temperature trends with model projections. Int J Climatol 2007; doi: 10.1002/ joc.1651 www.icecap.us/images/uploads/ DOUGLASPAPER.pdf (29.10.2010).

4. Monckton C. Foredrag i London 2009 www.youtube.com/watch?v=4zOXmJ4jd-8\& feature=player_embedded $(29.10 .2010)$

\section{Behov for leger som ledere}

Jeg er glad for at Tor Ingebrigtsen i Tidsskriftet nr. 20/2010 tar opp debatten om hvorfor leger blir, eller ikke blir, ledere (1). Legeforeningen jobber for at leger skal ta lederansvar. Det er stort behov for dyktige ledere blant legene, og jeg har tidligere oppfordret leger til å bli ledere (2).

Legeforeningen har bred kontakt med ledere i helsetjenesten og gir konkret bistand og veiledning til mange. Foreningen utarbeider veiledere hvor man retter seg både mot tillitsvalgte og ledere som støtte i ledelsesutøvelse. Veilederen om omstillingsprosesser gir lett tilgjengelig informa- 